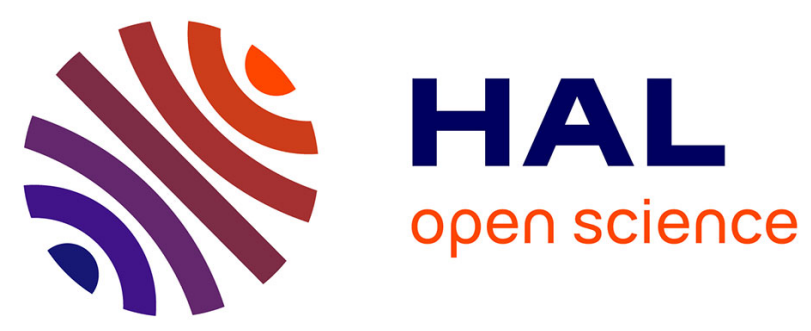

\title{
Source contributions of lead in residential floor dust and within-home variability of dust lead loading.
}

\author{
Jean-Paul Lucas, Lise Bellanger, Yann Le Strat, Alain Le Tertre, Philippe \\ Glorennec, Barbara Le Bot, Anne Etchevers, Corinne Mandin, Véronique \\ Sébille
}

\section{To cite this version:}

Jean-Paul Lucas, Lise Bellanger, Yann Le Strat, Alain Le Tertre, Philippe Glorennec, et al.. Source contributions of lead in residential floor dust and within-home variability of dust lead loading.. Science of the Total Environment, 2014, 470-471, pp.768-79. 10.1016/j.scitotenv.2013.10.028 . hal-01017419

HAL Id: hal-01017419

https://hal-univ-rennes1.archives-ouvertes.fr/hal-01017419

Submitted on 2 Jul 2014

HAL is a multi-disciplinary open access archive for the deposit and dissemination of scientific research documents, whether they are published or not. The documents may come from teaching and research institutions in France or abroad, or from public or private research centers.
L'archive ouverte pluridisciplinaire HAL, est destinée au dépôt et à la diffusion de documents scientifiques de niveau recherche, publiés ou non, émanant des établissements d'enseignement et de recherche français ou étrangers, des laboratoires publics ou privés. 


\section{Source Contributions of Lead in Residential Floor Dust and Within-Home Variability of}

\section{Dust Lead Loading}

Jean-Paul Lucas ${ }^{\mathrm{a}, \mathrm{b},{ }^{*}}$, Lise Bellanger ${ }^{\mathrm{c}}$, Yann Le Strat ${ }^{\mathrm{d}}$, Alain Le Tertre ${ }^{\mathrm{d}}$, Philippe Glorennec e,f , Barbara Le Bot ${ }^{\mathrm{e}, \mathrm{f}}$, Anne Etchevers ${ }^{\mathrm{f}}$, Corinne Mandin ${ }^{\mathrm{a}}$, Véronique Sébille ${ }^{\mathrm{b}}$

${ }^{\text {a } U n i v e r s i t e ́ ~ P a r i s ~ E s t ~-~ C S T B ~-~ C e n t r e ~ S c i e n t i f i q u e ~ e t ~ T e c h n i q u e ~ d u ~ B a ̂ t i m e n t, ~} 84$ avenue Jean Jaurès, 77447 Marne-la-Vallée Cedex 2, France

${ }^{\mathrm{b}}$ Université de Nantes - EA 4275 Biostatistique, Pharmacoépidémiologie et Mesures

Subjectives en Santé, 1 rue Gaston Veil BP 53508, 44035 Nantes Cedex 1, France

${ }^{\mathrm{c}}$ UMR CNRS 6629 Laboratoire de Mathématiques Jean Leray, 2 rue de la Houssinière BP 92208F, 44322 Nantes Cedex, France

${ }^{\mathrm{d}}$ InVS, 12 rue du Val d'Osne, 94415 Saint-Maurice Cedex, France

${ }^{\text {e }}$ EHESP Rennes, Sorbonne Paris Cité - Avenue du Professeur Léon-Bernard, CS 74312, 35043 Rennes Cedex, France

${ }^{\mathrm{f}}$ INSERM UMR 1085 Institut de Recherche sur la Santé, l'Environnement et le Travail, Rennes, France

* Corresponding author: CSTB, Direction Santé Confort/Expologie OQAI, 84 avenue Jean Jaurès, Champs-sur-Marne, 77447 Marne-la-Vallée Cedex 2, France. Tel.: +3316468 8839. Fax: +3316468 88 23. E-mail address: jean.paul.lucas@free.fr 


\begin{abstract}
Evidence of the impact of exposure to low levels of lead on children's health is increasing. Residential floor dust is the assumed origin of lead exposure by young children. In this study, we estimate the contribution of different lead sources to household interior floor dust contamination. We also estimate the within-home variability of interior floor dust lead loadings. A multilevel model was developed based on data collected in a French survey in 2008-2009 (484 housing units, 1834 rooms). Missing data were handled by multiple imputation using chained equations. The intra-home correlation between interior floor Log dust lead loadings was approximately 0.6. Dust lead from the landing of an apartment, mostly originating outside the building, was the major contributor to interior floor dust lead. Secondary contributors included the lead-based paint on exterior railings, track-in of the exterior soil of the children's play area into the dwelling, smoking inside the home, demolition of nearby old buildings and sites of pollution in the vicinity. Interior lead-based paint contaminated interior floor dust only in old and non-renovated dwellings. To reduce interior floor dust lead levels in the general population of dwellings, common areas should be maintained, and track-in from the outside should be limited as much as possible.
\end{abstract}

\title{
Keywords
}

Lead; House dust; Exposure; Multilevel modeling. 


\section{Funding}

This study was funded by the French Health Department (DGS). 


\section{Introduction}

Policy measures have reduced lead exposure in industrialized countries. In France, for example, these measures include the phase-out of leaded gasoline in 2000, a ban on the use of lead-based paint (LBP) by professionals in 1926 and 1948, and the establishment of housing lead hazard reduction methods in 1999. Consequently, blood lead levels (BLLs) have sharply decreased, notably in France. In 1996, the prevalence of elevated BLLs $(\geq 100 \mu \mathrm{g} / \mathrm{L}=10$ $\mu \mathrm{g} / \mathrm{dL}$ ) was estimated at 5\% in adults and $2 \%$ in children in France (INSERM 1999), decreasing to $1.7 \%$ in adults for the years $2006-2007$ (Falq et al. 2011) and to $0.11 \%$ in children for the period 2008-2009 (Etchevers et al., 2010).

Meanwhile, scientific evidence of the effects of exposure to low levels of lead in children is increasing (Canfield et al. 2003; Lanphear et al. 2005), and exposures that were previously considered low are still of concern. The "level of concern" equal to $100 \mu \mathrm{g} / \mathrm{L}$ at which intervention was previously recommended in the United States was lowered to the "reference value" of $50 \mu \mathrm{g} / \mathrm{L}(5 \mu \mathrm{g} / \mathrm{dL})$ in 2012 (ACCLPP 2012; CDC 2012). Similarly, in France, a reduction of the level of $100 \mu \mathrm{g} / \mathrm{L}$ to an as-yet undetermined threshold is underway. A further reduction of the lead levels in environmental media is an ongoing goal.

Dust is a major residential media of interest for lead exposure in children (Lanphear et al. 1998) and is the strongest predictor of BLL (Lanphear et al. 1996, 1998, 2002; Oulhote et al. 2013). Some authors have studied the contribution of different sources of lead to dust lead $(\mathrm{DPb})$ levels. For instance, Sturges and Harrison (1985) studied the contribution from paint flakes to the lead content of household dust, Lanphear and Roghmann (1997) demonstrated that the contribution of LBP was greater than the contribution of lead-contaminated soil, and Dixon et al. (2005) studied the migration of DPb from common areas in multiunit buildings into the associated dwelling. Other studies assessed the contamination of floor dust by lead 
sources in special contexts, such as around a lead mining unit (Sterling et al. 1998) or after LBP hazard control (Clark et al. 2004). To our knowledge, no study has assessed the joint contribution of numerous potential sources of lead to interior floor DPb levels. Moreover, previous results may be outdated because exposure reduction actions may have changed the relationships between the environmental media containing lead.

In addition, the number of wipes that must be used to sample house floor dust to ensure a representative sample of the level of lead in a home remains uncertain. According to the guidelines of the U.S. Department of Housing and Urban Development (HUD), either a minimum of 3 composite samples or at least 6 to 8 single-surface samples should be collected on floors, window sills, and window troughs (U.S. HUD 1995). More precisely, 1 composite sample from 4 rooms or 4 rooms with 1 single-surface sample should be collected. According to the French Institute for Public Health Surveillance (InVS), a single floor dust sample is insufficient for assessing the lead contamination level of a housing unit. Three single-surface samples per dwelling are recommended (Bretin 2006). However, these recommendations are not based on studies of the correlation between lead loadings in interior floor dust.

In this study, we estimate the contributions of potential lead sources to household interior floor $\mathrm{DPb}$ levels. We also estimate the within-home variability of interior floor $\mathrm{DPb}$ loadings to ascertain whether one dust sample is sufficient to estimate the $\mathrm{DPb}$ contamination level in a housing unit.

\section{Materials and methods}

\subsection{Surveys and study population}

Data were collected in a survey called Plomb-Habitat (PHS) that was conducted in France, excluding overseas regions, between October 2008 and August 2009. PHS was a nested survey in the Saturn-Inf survey (SIS). SIS was a prevalence survey of childhood lead 
poisoning that was conducted in hospitals and in which 3831 children were enrolled (Etchevers et al. 2010). Data were collected from the housing of a subsample of 484 children to study the relationship between BLLs and environmental lead. Thus, 484 primary residences (as opposed to second homes) of the sample of children were investigated (139 multi-dwelling units and 349 single-detached dwellings). Parents agreed to participate. For inclusion, the child had to have lived in the dwelling for at least 6 months prior to enrollment. This home sample was representative of 3,581,991 French housing units in which at least one child aged 6 months to 6 years lived in 2008 (Lucas et al. 2012).

\subsection{Sample collection}

PHS consisted of a face-to-face questionnaire and measurements. The questionnaire included approximately 350 items and collected information about housing characteristics, the outdoor environment, the specific behavior of the child, and more general information related to lead sources.

In each housing unit, up to 5 rooms were investigated, including the child's bedroom, the living room, the main entrance, the kitchen, the bedroom of another child, and the playroom. For each investigated room, a single-surface sample of interior floor dust was collected by wipe sampling $\left(\mu \mathrm{g} / \mathrm{m}^{2}\right)$ according a standard protocol (ASTM 2003). The different building elements of each room were measured with an X-ray fluorescence lead-based paint analyzer $\left(\mathrm{mg} / \mathrm{cm}^{2}\right)$ in accordance with the French regulatory protocol (AFNOR 2008c); a single brand was used (Niton). Paint chips were collected if the occupant agreed. Among the 484 housing units, 1834 rooms were investigated. If the child usually played outside of the home, the ground of his or her play area was sampled by wiping according to the same protocol as inside if its surface was a hard surface $\left(\mu \mathrm{g} / \mathrm{m}^{2}\right)$ or by coring if it was soil $(\mathrm{mg} / \mathrm{kg})$. For soil, a 
composite sample (10 samples) was taken from the 0 to $2 \mathrm{~cm}$ layer and prepared according to a standard protocol (AFNOR 2006).

Samples were analyzed by inductively coupled plasma mass spectrometry. The limits of quantification (LOQ) were $2 \mu \mathrm{g} / \mathrm{m}^{2}$ for dust and $1.3 \mathrm{mg} / \mathrm{kg}$ for soil. Total and leachable lead concentrations or loadings were determined for each sample (Le Bot et al. 2011).

The details of the sample collection and data quality have been described extensively elsewhere (Lucas et al. 2012).

\subsection{Statistical analysis}

\subsubsection{Modeling}

We developed a model in which a set of covariates denoted $X$ (in particular, the lead sources) explains a response variable denoted $Y$ (the interior floor dust Log lead loadings). Classical linear regression is associated with single-level modeling. Because here we collected data about two different levels - rooms and dwellings - single-level linear regression was not an appropriate modeling method to take into account the non-independence between floor $\mathrm{DPb}$ loadings within a dwelling. Thus, we used a multilevel model (MLM), also known as a mixed model or hierarchical model. Related equations and assumptions are described in the supplementary information. Rooms are called level-1 units and dwellings level-2 units.

The response variable was Log-transformed by natural logarithm $\left(\log \equiv \log _{\mathrm{e}}\right)$ to allow us to approach the hypothesis of normality required for the errors in the model. Numerical covariates were also Log-transformed because such a transformation provides a good model to explain variability in the observations for lead exposure data (Jiang and Succop 1996; Rust et al. 1997). When covariate $X$ had null values, the $\log$-transformation was $\log (X+1)$, and it was $\log (X)$ otherwise. 
The within-home variability was represented by $1-\rho$, where $\rho$ is the intraclass correlation coefficient equal to $\sigma_{L}^{2} /\left(\sigma_{L}^{2}+\sigma_{\epsilon}^{2}\right)$ and a measure of reproducibility of replicate measures from the same subject (home).

Because the data were obtained from a survey, weights should be used in the statistical method for fitting an MLM, called the pseudo-maximum likelihood (Rabe-Hesketh and Skrondal 2006). MLM on survey data is an active area of research in applied statistics. The existing literature focuses on appropriate choices for weights of level-1 units when these units are selected with unequal probabilities (Pfeffermann et al. 1998; Carle 2009). Level-1 weights were not an issue in this study because rooms were not randomly selected. Rooms were automatically investigated if they belonged to the list indicated in section 2.2. No scientific paper seems to have studied level-2 weights precisely. In a related simulation study of our data, we determined that it was better not to introduce level- 2 weights and to ultimately fit an unweighted model (Lucas et al. 2013).

\subsubsection{Selection of covariates}

Covariates were classified either as lead sources able to contaminate interior floor dust or as confounders. Confounders were defined as uninteresting reasons why $X$ and $Y$ would be related. A source was selected if it was previously listed either as a potential source of lead in dust directly or as a contributor to BLL (see Table A.1 in the appendix). Sources not yet studied or poorly studied were introduced in the model to estimate the effects of all available potential sources. The selected covariates and their modalities are fully described in Table

\section{A.2.}

The location of the floor entrance, the season, the frequency of cleaning the floor of the investigated rooms (by wet and dry methods), whether the floor of the landing was able to be cleaned by a wet method, the type of room, and the dust sample location in the room were 
introduced as confounders. Information about floor cleaning was very important because lead measures in floor dust were expressed as loadings, and thus they depended on the level of dust accumulation.

Because we were only interested in estimating the effects of lead sources on interior floor dust contamination, risk factors correlated with covariates used in the model as sources were not introduced in the model to prevent these from influencing the modeled effect of actual lead sources. For instance, because we assumed that the lead loadings in paint were related to the year of construction of the building, the year of construction was not included in the model.

\subsubsection{Censored and missing data}

$\mathrm{DPb}$ loadings lower than the LOQ were replaced by a random value from a uniform distribution on the interval ]0; LOQ[; zero was excluded to avoid problems with the Logtransformation. Because the proportion of values below the LOQ is not elevated (approximately $10 \%$ ), replacing these values with a single, random value should not lead to bias (Lubin et al. 2004). The replacement concerned 205 loadings of 1834 for interior floor dust. No dust and no soil from the exterior play areas were replaced.

Among the variables used in our model, less than $0.6 \%$ of the values were missing, which resulted in the loss of approximately $12.5 \%$ of the observations (rooms). To avoid dropping observations with missing values and thus losing valuable information and eventually inducing bias (Sterne et al. 2009), we handled missing values with a multiple imputation (8 variables concerned). There is no definitive recommendation in the literature on the best way to impute survey data (Kim et al. 2006; Reiter et al. 2006). We used a flexible method called imputation by chained equation (ICE) (White et al. 2011) or fully conditional specification (FCS) (van Buuren et al. 1999). We performed multiple imputation with $\mathrm{M}=100$ replications. 
The results obtained after multiple imputation were considered for discussion; however, we also display the results for the complete case, as recommended by Sterne et al. (2009).

\subsubsection{Reported results}

Interior floor DPb loadings, lead concentrations in the soil or dust of the exterior play areas, and floor DPb loadings in common areas have been described previously (Lucas et al. 2012).

Coefficient estimates were presented with their $95 \%$ confidence intervals. To assess the contribution of the original numerical covariate $X$ on original lead loadings $Y$, it is sensible to estimate the change in $Y$ when $X$ is changed by an amount that is subject-matter relevant (Harrell 2001). Changing $X$ from its 0.25 quantile to its 0.75 quantile is useful because this change represents a span that contains half of the sample values of $X$. Because our original numerical covariates were highly right-skewed, we also show the change in $Y$ when $X$ changed from its 0.50 quantile to its 0.90 quantile, from its 0.50 to its 0.95 quantile, and from its 0.90 to its 0.975 quantile. Because the higher the quantile order, the lower the estimate precision, we chose not to go higher than the 0.975 quantile. Thus, source contributions (expressed in \% increase in the response variable $Y$ ) were computed by $100 \times\left[\left(x_{1} / x_{0}\right)^{\hat{a}}-1\right] \%$ for a covariate $\log$-transformed with $\log (X), 100 \times\left[\left(x_{1}+1 / x_{0}+1\right)^{\hat{a}}-1\right] \%$ for a covariate $\log$ transformed with $\log (X+1)$, and $100 \times[\exp (\hat{a})-1] \%$ for binary variable changing from 0 to 1 , where $x_{0}$ is the quantile of lowest order in the change of $X$ (e.g., the 0.25 quantile), $x_{1}$ is the quantile of highest order in the change of $X$ (e.g., the 0.75 quantile), and $\hat{a}$ is the estimate of regression coefficient $a$ of covariate $X$.

A covariate was estimated as a suspected source of lead based on a positive coefficient estimate. The level of contribution allowed us to determine whether a covariate had an important effect on $Y$ relative to the other covariates. Evidence of the effect was judged 
according to our $95 \%$ confidence interval (whether it included 0 ) as well as consistency with previous published results.

Results are shown for total lead in this paper. The results for leachable lead are available in the supplementary information because French regulations are based on leachable lead and not total lead (AFNOR 2008a, 2008b, 2008c). DPb loadings are expressed in micrograms per square meter $\left(1 \mu \mathrm{g} / \mathrm{m}^{2}=0.09290304\right.$ micrograms per square foot $\left.\left(\mu \mathrm{g} / \mathrm{ft}^{2}\right)\right)$.

\subsubsection{Software}

Databases were managed and cleaned with SAS (SAS System for Windows, version 9.1.3; SAS Institute Inc., Cary, NC, USA) and exported to Stata for analysis (StataCorp 2011, Stata Statistical Software: Release 12. College Station, TX: StataCorp LP). The "mi impute chained" command in Stata was used for the multiple imputation, and the "xtmixed" command was used to fit the 2-level model (StataCorp 2011).

\section{Results}

\subsection{Source contributions}

Table 1 shows the estimated distribution of covariates of the model, which was used to estimate their contribution. Null values for some percentiles of "Ext playground soil" and "Ext playground dust" are explained by the construction of these covariates themselves in the interaction with the frequency of visit of the play area by the child (see appendix A; see also Table 5 of Lucas et al. (2012) for the distribution of the lead levels in exterior soil and dust). Table 2 provides the parameter estimates in the fitted MLM with their 95\% confidence interval.

Interior floor $\mathrm{DPb}$ was associated with all potential sources except "Ext work", the exterior renovations, and " $\log ($ Contaminated sites +1$)$." Although the interpretation of the confounder 
estimates was not of interest, they are shown to enable comparisons with other studies. Figure 1 demonstrates the magnitude of the contribution on interior floor DPb loadings. A change from their respective 0.25 quantile to their respective 0.75 quantile involved a noticeable increase in interior floor DPb loadings for "DPb-landing," "Ext playground soil/Often," "Polluting sites," and "Surrounding demolition" (and also "Ext playground soil/Always" for the leachable lead model: see supplementary information). The increase in interior floor $\mathrm{DPb}$ loadings due to "XRF ext railings" is only substantial for a change from its 0.50 quantile to its 0.95 quantile ( 0 to $2.6 \mathrm{mg} / \mathrm{cm}^{2}$ ) as well as "Smoking inside" ( 0 to $1.5 \mathrm{~h} /$ day). However, these latter two sources were able to contribute to a greater extent when they reached their highest observed values. The contribution of interior deteriorated LBP and interior LBP in the usual condition could be detected only for values greater than the 0.975 quantile and from the 0.95 quantile, respectively. However, even if their highest values were reached, their contributions to the increase in interior floor $\mathrm{DPb}$ loadings would remain lower than the contribution of the other sources listed above. Thus, as displayed in Figure 1, lead in landing dust was by far the largest contributor. A change in the DPb loading of the landing floor from 0 to $7.7 \mu \mathrm{g} / \mathrm{m}^{2}$ (approximately $0.7 \mu \mathrm{g} / \mathrm{ft}^{2}$ ) would produce an approximately $122 \%$ increase in the interior floor $\mathrm{DPb}$ loading. The increase is approximately $700 \%$ when the $\mathrm{DPb}$ loading of the landing of the apartment changes from $0 \mu \mathrm{g} / \mathrm{m}^{2}$ to its 0.975 quantile $\left(172 \mu \mathrm{g} / \mathrm{m}^{2}\right.$, i.e., $\left.16 \mu \mathrm{g} / \mathrm{ft}^{2}\right)$. Figure 1 also shows that "Surrounding demolition" contributed to the contamination of interior floor dust. The detailed results used to plot Figure 1 are available in the supplementary information. Table 2 shows that estimates, their sign, and their evidence are relatively stable between the imputed data and the complete case. The results for contributions obtained from the complete case are available in the supplementary information.

\section{Insert Tables 1 and 2}




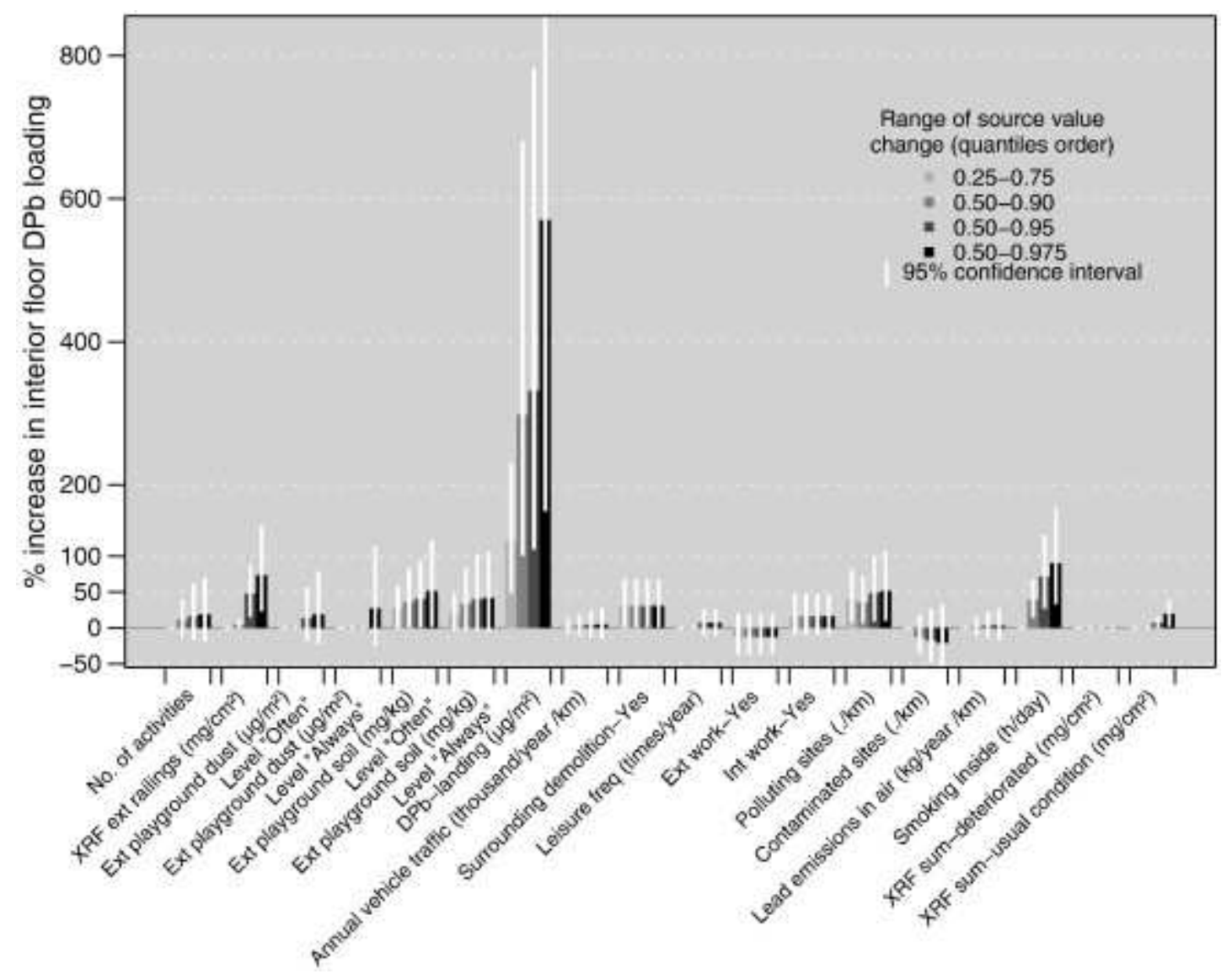

Figure 1. Contribution of each source expressed in \% increase in interior floor dust lead $(\mathrm{DPb})$ levels $\left(\mu \mathrm{g} / \mathrm{m}^{2}\right)$, based on imputed data $(\mathrm{M}=100$ data sets).

\subsection{Within-home variability of floor DPb loadings}

The variance parameters, $\sigma_{L}^{2}$ and $\sigma_{\epsilon}^{2}$, were estimated at $1.039(95 \% \mathrm{CI}=0.879-1.227)$ and $0.643(95 \% \mathrm{CI}=0.566-0.731)$, respectively. Thus, intraclass correlation coefficient $\rho$ had an estimated value of 0.618 . The within-home variability was approximately equal to $38 \%$; in other words, the correlation between two Log floor DPb loadings in the same home was approximately equal to 0.62 . In the complete case, the result was approximately the same.

\section{Discussion}

\subsection{Source contributions}


Most of the potential sources of lead investigated were confirmed. Although many confidence intervals were large, they might still be sufficiently precise to decide which prevention measures are sufficiently useful that they should not be postponed.

\subsubsection{Sources related to the activities of household members}

Occupational activities and leisure related to lead. These sources have been previously studied as BLL predictors (Sanborn et al. 2002; Schapiro and Bretin 2006) but never as DPb sources. Many occupational activities related to lead (at least 4 or 5) practiced by the members of the household could increase DPb loadings of interior floor dust. However there is no statistical evidence of their effect. The same observation could be made for inside leisure related to lead.

Smoking. Studies of the contribution of lead from tobacco smoke to housing lead contamination have been limited. We observed a $40 \%$ increase in lead loadings in response to $1.5 \mathrm{~h}$ of smoking indoors per day. These results are in accordance with Gaitens et al. (2009). This situation concerns $10 \%$ of French households.

\subsubsection{Sources related to the outdoor environment}

Lead in exterior soil and in exterior dust of the children's play area. The track-in of lead from exterior soil to interior floor dust seems to be substantial. Exterior soils were already suspected as a major source of lead in interior dust (Hunt et al. 2012). However, no study has quantified the contribution of lead in exterior soil to the lead of interior floor dust; most studies have described the relationship with BLLs. Lanphear and Roghmann (1997) found that the contribution of LBP to DPb levels was greater than that of lead-contaminated soil, but these data were collected 15 years ago. Relationships between different environmental media containing lead may have changed due to emission reduction actions that have occurred. 
Similar observations can be made regarding exterior dust. For instance, Clark et al. (2004) studied the pathway from exterior dust to interior dust, but that study concerned exterior entry dust and not play areas. Moreover, the relationship was not quantified. With our data, no strength of evidence was obtained regarding the influence of exterior dust on the contamination of the interior floor dust (0 lay within the confidence intervals). This finding may be due to the small number of exterior dust samples that were collected (53 available loadings for exterior dust and 315 available concentrations for exterior soil). Moreover, the lack of evidence may also be because the apartment landing dust covariate may have captured part of the effect of the exterior dust covariates (see, also, "Floor DPb of the landing of the apartment" in section 4.1.3 below).

Vehicle traffic from the closest road. The contribution of vehicle traffic from the closest road was not important regarding the response variable (no more than an approximate $10 \%$ increase), and there was no evidence at all of its effect.

Demolition. The demolition of old buildings increased the dust lead level by approximately 30\%. This effect was observed previously by Rabito et al. (2007) in the BLL of children when multiple demolitions occurred. Dixon et al. (2012) found a greater contribution, but their variable "nearby demolition" also included the presence of smelters, battery plants, or other potential lead sources. Thus, our results confirm the role of demolitions around the dwelling in the lead contamination of interior floor dust.

Polluting sites and contaminated sites. Soil abatement near polluting sites such as smelters or milling plants was found to reduce the lead level in interior floor dust (Lanphear et al. 2003). Our findings confirm the influence of such polluting sites: they increased the lead level in dust by 40 to $50 \%$. A change from its 0.25 quantile to its 0.75 quantile produced an increase 
among the top 3 contributions. An unexpected result was obtained for the "Contaminated sites" covariate, but there was no evidence of its negative contribution.

Lead emissions in air. The contribution of lead emissions in the air to the contamination of interior floor dust was estimated as very low (only a few percent), even for the highest observed values; moreover, there was no evidence of its effect. Layton and Beamer (2009) demonstrated that airborne lead was the main source of lead in interior floor dust by analyzing data on lead contamination in Sacramento, CA, United States, in the early 1980s and assumed that after the phase-out of leaded gasoline, soil track-in was the major source of lead contamination of interior floor dust. Our results are quite consistent with this assumption.

\subsubsection{Sources related to the building indoor features}

Floor DPb of the landing of the apartment. The lead in dust of the apartment landing was the most important contributor to the lead contamination of the interior floor dust. We previously reported (Lucas et al. 2012) that lead loadings were 4 times higher in common areas than inside apartments; the prevalence of LBP was also higher: 7.1\% (CI 95\% $=1.8-12.4 \%$ ) vs. $4.7 \%(\mathrm{CI}=2.4-6.9 \%)$. These previous findings and the results of the present study are consistent with Dixon et al. (2005), who studied the influence of common-area lead hazards. $\mathrm{DPb}$ from the landing is tracked into the home through the natural flow caused by the movements of people or on clothing and shoes. Dixon et al. (2005) assumed that leaded paint was a source of floor $\mathrm{DPb}$ in the common areas as well as exterior soil and dust tracked into the common areas. To verify this assumption, we replaced in our model the " $\mathrm{DPb}$-landing" covariate with a covariate indicating the maximal XRF value measured in paints of the landing of the apartment. The coefficient of this covariate was estimated to be close to zero: $0.004(95 \% \mathrm{CI}=-0.13 ; 0.138)$ compared to $0.369(95 \% \mathrm{CI}=0.189 ; 0.549)$ for the " $\mathrm{DPb}-$ landing" covariate. Moreover, little change occurred in estimates of other source coefficients. 
This result shows that the floor $\mathrm{DPb}$ of the landing comes mainly from outside the landing and not from the LBP in the common areas. Thus, part of the important contribution of the lead found in the dust of the apartment landing actually originates in exterior soil and dust. However, we cannot exclude that lead in the common areas dust might also come from inside the home itself.

Interior work. Interior work throughout the 6 months before the investigation increased the lead level in interior floor dust by approximately $16 \%$ (CI 95\% = -7;45). Dixon et al. (2012) demonstrated a contribution of specific renovation work but not for general renovation work, which is consistent with our findings.

Interior LBP. Our model does not highlight the role of interior LBP in the contamination of interior floor dust because lead loadings in paint are low in deteriorated coatings. Only nonrenovated, old, poor housing is still affected by the contamination of interior floor dust by interior LBP. Indeed, the investigated housing units with a room exceeding only $30 \mathrm{mg} / \mathrm{cm}^{2}$ included 3 units built before 1915 and 1 unit built in the period 1915-1948 for the lead-based deteriorated paint covariate; 7 units built before 1915, 5 units built in the period 1915-1948, and only one unit built between 1949 and 1974 for the LBP in usual condition covariate.

\subsubsection{Sources related to the building outdoor features}

LBP of exterior railings. Paint lead loadings on exterior railings was one of the main sources of lead in interior floor dust but only if the paint contained at least $2.6 \mathrm{mg} / \mathrm{cm}^{2}$. In this case, the interior floor DPb loading is increased by approximately $50 \%$. Lead tetraoxide (red lead) was widely used in France in exterior paint for protection against rust until the mid-1990s (Lucas 2011; Lucas et al. 2012). No studies have considered the contamination of interior floor dust by exterior railings coated with leaded paint. However, as far back as 1904, J. Lockhart Gibson strongly believed that railings were responsible for lead poisoning in 
children (Gibson 2005). The contribution of exterior painted railings to interior dust contamination is not easily interpreted because the painted surface is generally not large. We first interpreted this contribution as a proxy, e.g., these railings could indicate the presence of an outdoor area, such as a balcony or terrace, where exterior contaminated dust could settle or pile up (Tong and Lam 2000). However, replacing the covariate "XRF ext railings" with a covariate indicating the presence or the absence of such an outdoor area did not confirm this assumption.

Exterior work. We found that recent exterior work such as restoration or sandblasting for example, had a minor negative contribution (from $-17 \%$ to $-12 \%$ ) to the contamination of interior floor dust, in agreement with the findings of Reissman et al. (2002) and Dixon et al. (2012). In these studies and ours, evidence of this protective effect for interior floor dust was not shown. However, Clark et al. (2011) demonstrated that exterior work could be beneficial for lowering BLL in children when exterior lead loadings were elevated $\left(>7.0 \mathrm{mg} / \mathrm{cm}^{2}\right)$.

\subsection{Within-home variability}

Determining whether a correlation of approximately $60 \%$ between two Log DPb loading replicates within a housing unit is sufficient to assure that only one dust sample can represent the $\mathrm{DPb}$ level is complex. Usually an interpretation of such a value is that a value between $40 \%$ and $75 \%$ indicates fair to good reproducibility (Rosner 2006), but this conclusion is complicated because not all rooms of each housing unit were investigated. Although data from a few studies, such as Wilson et al. (2007), could be used to estimate this within-home variability, our study is the first to provide such an estimate for lead.

\subsection{Covariates and modeling}

The distributions of the numerical sources were very right-skewed, and their contribution was particularly apparent at their high quantiles. This pattern may seem a bit disturbing, but these 
distributions are actually not Gaussian at all, particularly for lead level variables. The influence on lead in dust is currently only apparent with the extreme values of the potential sources.

We highlighted that landing dust would have captured part of the effect of the exterior sources. However, it would have been careless not to introduce all these sources into the model. Indeed, it seemed unlikely that there was no direct effect of exterior sources on interior floor dust. Moreover, single-detached dwellings do not include a landing ("DPb-landing" was set to 0); thus, exterior sources should been used in the model for this home type. Exterior sources therefore were not completely double-counted. A further study of these complex relationships between residential environmental media could be performed by multilevel structural equation modeling (Rabe-Hesketh et al. 2007).

Lead in housing was and is still commonly associated with LBP. For interior LBP, we used two non-classical variables: we summed the XRF measurements of a room by coating condition. The maximum of the XRF measurements is often used but is not ideal information because the coating condition must be considered when estimating the overall lead level in paint inside a room or a dwelling and the LBP hazards of a dwelling. An ideal XRF variable would even be a weighted sum of the XRF measurements, where the weights would be the surface area of each building element measured. However, measuring the surface area of each building part is very difficult to implement in a large-scale survey and may lead to many missing values, as occurred in our survey. The historical use in models of the maximum XRF measurement may have overestimated the effect of interior LBP on interior floor DPb levels.

The coefficient of determination $\left(\mathrm{R}^{2}\right)$, the goodness-of-fit measure for (single-level) linear regression, is not available for multilevel models. Although several methods have been proposed (Kramer 2005), there is no widely accepted measure of $\mathrm{R}^{2}$ for mixed models. To 
assess the quality of our model, we display the residual distribution in Figure 2. The assumption of normality for the residuals seems to be valid. Moreover Figure 3 shows that the extreme Log DPb loadings are moderately fitted by the model, but the global fit is fairly adequate.

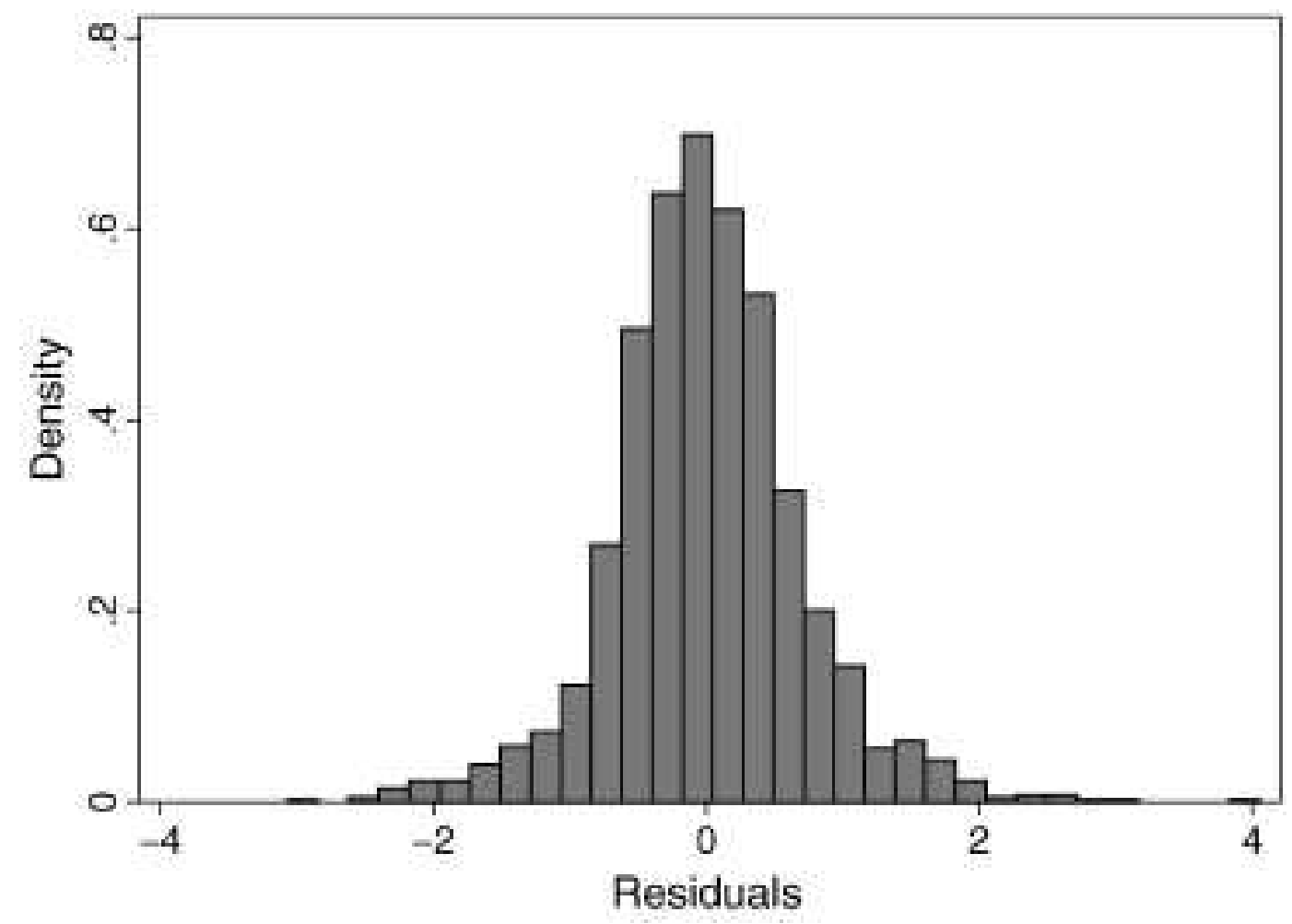

Figure 2. Two-level model residuals for Log interior floor dust lead loading. 


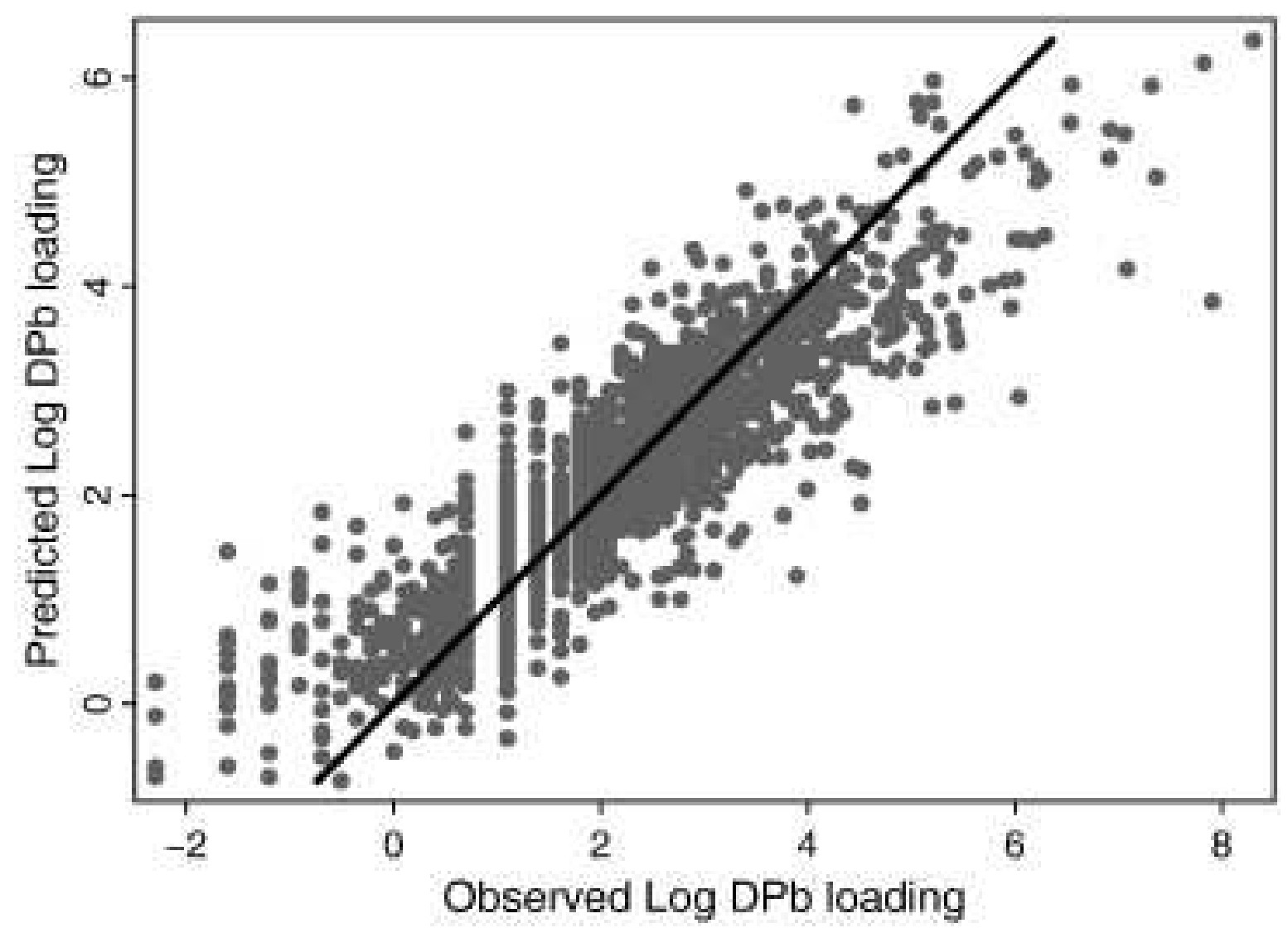

Figure 3. Predicted Log interior floor dust lead (DPb) loadings versus observed Log loadings $\left(\mu \mathrm{g} / \mathrm{m}^{2}\right)$. Black line: $y=x$.

\section{Conclusion}

We assessed the source contribution of lead in residential floor dust, including known and potential sources. To reduce the lead exposure of interior floor dust, common areas should be renovated and cleaned as much as possible. Exterior painted railings should be maintained. The track-in from the outdoor play areas on soil into the dwellings should be limited, especially when surrounding are contaminated. Simple precautions could be to take shoes off before entering the home or to use walk-off mats. Furthermore, precautions must be taken when surrounding old buildings are demolished. Contamination by interior LBP is no longer important for most dwellings. Special attention should be paid to smoking, which can contaminate interior floor dust when one smokes inside a few hours a day. 
The correlation between two measurements of lead in floor dust taken within a single home is approximately 0.6 . This new result should be confirmed by further studies. However, the decision regarding the number of interior floor dust samples to take should consider the objective of the measurement as well as cost.

\section{Appendix A. Model Covariates}

Table A.1 lists studies in which the information given by the covariates of our model was associated with the DPb level or with the BLL. Table A.2 describes the covariates introduced in the model. Details about how some of the covariates were built are provided. 


\section{Tables}

Table 1. Distribution of the covariates used in the model.

\begin{tabular}{|c|c|c|c|c|c|c|c|}
\hline \multirow{2}{*}{$\begin{array}{l}\text { Covariate } X \\
\text { Quantile order }\end{array}$} & & \multicolumn{6}{|c|}{ Quantile (numeric covariates) or frequency (discrete covariates) } \\
\hline & & 0.25 & 0.50 & 0.75 & 0.90 & 0.95 & 0.975 \\
\hline Floor entrance ${ }^{*, a}$ & & \multicolumn{6}{|c|}{ Semi-buried (5.8\%); First floor (61\%); Upstairs (33.2\%) } \\
\hline Season & & \multicolumn{6}{|c|}{ Autumn/winter (30.4\%); Spring/summer (69.6\%) } \\
\hline Wet cleaning landing floor & & \multicolumn{6}{|c|}{ No landing (72.4\%); Yes (23.4\%); No (4.2\%) } \\
\hline Type of room & & \multicolumn{6}{|c|}{ Bedroom (34.6\%); Entryway (12.9\%); Living room (26.1\%); Kitchen (19.8\%); Playroom (6.5\%) } \\
\hline Wet cleaning freq-room (No. of times/week) & & 1 & 2 & 3 & 7 & 7 & 7 \\
\hline Dry cleaning freq-room (No. of times/week) & & 2 & 3 & 7 & 7 & 10 & 15 \\
\hline Dust sample location & & \multicolumn{6}{|c|}{ At the favorite place to play $(40.2 \%)$; In the middle of the room $(59.8 \%)$} \\
\hline No. of activities & & 0 & 0 & 0 & 2 & 4 & 5 \\
\hline XRF ext railings $\left(\mathrm{mg} / \mathrm{cm}^{2}\right)$ & & 0 & 0 & 0 & 0.2 & 2.6 & 5.1 \\
\hline \multirow[t]{2}{*}{ Ext playground dust $\left(\mu \mathrm{g} / \mathrm{m}^{2}\right)$} & Often $*, b$ & 0 & 0 & 0 & 0 & 20 & 53 \\
\hline & Always *,c & 0 & 0 & 0 & 0 & 0 & 91 \\
\hline \multirow[t]{2}{*}{ Ext playground soil (mg/kg) } & Often $*$,d & 0 & 0 & 23.0 & 64.6 & 97.6 & 267.5 \\
\hline & Always & 0 & 0 & 10.3 & 53.4 & 102.1 & 118.5 \\
\hline DPb-landing $\left(\mu \mathrm{g} / \mathrm{m}^{2}\right)^{*, \mathrm{e}}$ & & 0 & 0 & 7.7 & 41.1 & 51.7 & 172.5 \\
\hline Annual vehicle traffic (thousand/year $/ \mathrm{km}$ ) $*, \mathrm{f}$ & & 18 & 44 & 135 & 627 & 1210 & 2222 \\
\hline Surrounding demolition & & \multicolumn{6}{|c|}{ Yes $(11.1 \%) ;$ No $(88.9 \%)$} \\
\hline Leisure freq (times/year) & & 0 & 0 & 0 & 0 & 1 & 1 \\
\hline Ext work & & \multicolumn{6}{|c|}{ Yes $(7.3 \%) ;$ No $(92.7 \%)$} \\
\hline Int work & & \multicolumn{6}{|c|}{ Yes $(29 \%) ;$ No $(71 \%)$} \\
\hline Polluting sites $(. / \mathrm{km})$ & & 0 & 3.5 & 29.6 & 100.2 & 252.0 & 314.3 \\
\hline Contaminated sites $(. / \mathrm{km})$ & & 0 & 0 & 0 & 1.2 & 2.2 & 3.1 \\
\hline Lead emission in air $(\mathrm{kg} /$ year $/ \mathrm{km})$ & & 0 & 0 & 0 & 0.6 & 1.0 & 1.3 \\
\hline Smoking inside (h/day) ${ }^{*, \mathrm{~g}}$ & & 0 & 0 & 0 & 1.5 & 3.5 & 5 \\
\hline XRF sum-deteriorated $\left(\mathrm{mg} / \mathrm{cm}^{2}\right)$ & & 0 & 0 & 0 & 0 & 0 & 0 \\
\hline XRF sum-usual condition $\left(\mathrm{mg} / \mathrm{cm}^{2}\right)$ & & 0 & 0 & 0 & 0 & 1.1 & 5.9 \\
\hline
\end{tabular}




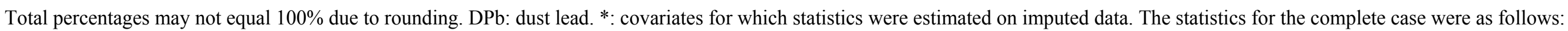
a: $5.8 \%, 61 \%, 33.2 \%$

b: $0,0,0,0,13,24$

c: $0,0,0,0,0,32$.

d: $0,0,23.0,64.6,97.6,267.5$.

e: $0,0,5,36,46,82$.

f: $18,44,135,627,1210,2222$.

g: $0,0,0,1.5,3.5,5$.

Table 2. Two-level model results for Log interior floor dust lead loading. $M=100$ imputed data sets.

\begin{tabular}{|c|c|c|c|c|c|}
\hline \multirow[b]{2}{*}{ Covariate } & & \multicolumn{2}{|c|}{ Imputed data (No. Obs. $=1834)$} & \multicolumn{2}{|c|}{ Complete case $($ No. Obs. $=1595)$} \\
\hline & Levels & Estimate & 95\% CI & Estimate & $95 \%$ CI \\
\hline Intercept & & 1.046 & $(0.262 ; 1.83)$ & 1.166 & $(0.327 ; 2.005)$ \\
\hline \multicolumn{6}{|l|}{ Confounders: } \\
\hline \multirow[t]{3}{*}{ Floor entrance } & Semi-buried & Ref & & ref & \\
\hline & First floor & 0.262 & $(-0.371 ; 0.896)$ & 0.196 & $(-0.455 ; 0.847)$ \\
\hline & Upstairs & 0.520 & $(-0.201 ; 1.242)$ & 0.547 & $(-0.187 ; 1.282)$ \\
\hline \multirow[t]{2}{*}{ Season } & Autumn/winter & Ref & & ref & \\
\hline & Spring/summer & 0.274 & $(0.052 ; 0.497)$ & 0.286 & $(0.047 ; 0.526)$ \\
\hline \multirow[t]{3}{*}{ Wet cleaning landing floor } & No landing & Ref & & ref & \\
\hline & Yes & -1.675 & $(-2.328 ;-1.022)$ & -1.466 & $(-2.05 ;-0.882)$ \\
\hline & No & -1.853 & $(-2.777 ;-0.929)$ & -1.557 & $(-2.289 ;-0.826)$ \\
\hline \multirow[t]{5}{*}{ Type of room } & Bedroom & -0.480 & $(-0.628 ;-0.331)$ & -0.522 & $(-0.68 ;-0.363)$ \\
\hline & Entryway & ref & & ref & \\
\hline & Living room & -0.201 & $(-0.330 ;-0.072)$ & -0.243 & $(-0.375 ;-0.111)$ \\
\hline & Kitchen & -0.012 & $(-0.122 ; 0.097)$ & -0.002 & $(-0.116 ; 0.111)$ \\
\hline & Playroom & -0.345 & $(-0.595 ;-0.095)$ & -0.384 & $(-0.632 ;-0.136)$ \\
\hline $\log ($ Wet cleaning freq-room+1) & & 0.178 & $(0.032 ; 0.325)$ & 0.142 & $(-0.009 ; 0.292)$ \\
\hline Log(Dry cleaning freq-room+1) & & -0.011 & $(-0.141 ; 0.119)$ & -0.011 & $(-0.147 ; 0.126)$ \\
\hline \multirow[t]{2}{*}{ Dust sample location } & Favorite place to play & ref & & ref & \\
\hline & Middle & 0.036 & $(-0.070 ; 0.141)$ & 0.001 & $(-0.111 ; 0.113)$ \\
\hline Sources: & & & & & \\
\hline $\log ($ No. of activities +1$)$ & & 0.096 & $(-0.099 ; 0.291)$ & 0.141 & $(-0.063 ; 0.345)$ \\
\hline
\end{tabular}




\begin{tabular}{|c|c|c|c|c|c|}
\hline \multirow[b]{2}{*}{ Covariate } & \multirow[b]{2}{*}{ Levels } & \multicolumn{2}{|c|}{ Imputed data $($ No. Obs. $=1834)$} & \multicolumn{2}{|c|}{ Complete case $($ No. Obs. $=1595)$} \\
\hline & & Estimate & $95 \%$ CI & Estimate & $95 \%$ CI \\
\hline Log(XRF ext railings +1$)$ & & 0.306 & $(0.125 ; 0.486)$ & 0.407 & $(0.19 ; 0.625)$ \\
\hline \multirow[t]{3}{*}{$\log ($ Ext playground dust +1$)$} & Does not play outside & ref & & ref & \\
\hline & Often & 0.043 & $(-0.058 ; 0.144)$ & 0.064 & $(-0.059 ; 0.186)$ \\
\hline & Always & 0.053 & $(-0.059 ; 0.165)$ & 0.093 & $(-0.033 ; 0.219)$ \\
\hline \multirow[t]{3}{*}{ Log(Ext playground soil+1) } & Does not play outside & ref & & ref & \\
\hline & Often & 0.074 & $(0.007 ; 0.141)$ & 0.075 & $(0.004 ; 0.146)$ \\
\hline & Always & 0.073 & $(-0.005 ; 0.150)$ & 0.073 & $(-0.009 ; 0.154)$ \\
\hline $\log (\mathrm{DPb}$-landing+1) & & 0.369 & $(0.189 ; 0.549)$ & 0.255 & $(0.129 ; 0.38)$ \\
\hline $\log ($ Annual vehicle traffic) & & 0.012 & $(-0.035 ; 0.059)$ & 0.007 & $(-0.046 ; 0.061)$ \\
\hline \multirow[t]{2}{*}{ Surrounding demolition } & No & ref & & ref & \\
\hline & Yes & 0.268 & $(0.028 ; 0.508)$ & 0.313 & $(0.049 ; 0.578)$ \\
\hline $\log ($ Leisure freq +1$)$ & & 0.097 & $(-0.118 ; 0.313)$ & 0.092 & $(-0.13 ; 0.314)$ \\
\hline \multirow{2}{*}{ Ext work } & No & ref & & ref & \\
\hline & Yes & -0.133 & $(-0.431 ; 0.165)$ & -0.067 & $(-0.378 ; 0.244)$ \\
\hline \multirow[t]{2}{*}{ Int work } & No & ref & & ref & \\
\hline & Yes & 0.149 & $(-0.076 ; 0.374)$ & 0.105 & $(-0.119 ; 0.328)$ \\
\hline $\log ($ Polluting sites +1$)$ & & 0.098 & $(0.026 ; 0.17)$ & 0.109 & $(0.032 ; 0.186)$ \\
\hline $\log ($ Contaminated sites +1$)$ & & -0.165 & $(-0.520 ; 0.191)$ & -0.104 & $(-0.58 ; 0.373)$ \\
\hline $\log ($ Lead emission in air +1$)$ & & 0.040 & $(-0.188 ; 0.269)$ & 0.169 & $(-0.154 ; 0.492)$ \\
\hline $\log ($ Smoking inside +1$)$ & & 0.359 & $(0.170 ; 0.547)$ & 0.339 & $(0.157 ; 0.521)$ \\
\hline Log(XRF sum-deteriorated+1) & & 0.166 & $(0.057 ; 0.276)$ & 0.171 & $(0.086 ; 0.255)$ \\
\hline $\log (\mathrm{XRF}$ sum-usual condition+1) & & 0.093 & $(0.022 ; 0.164)$ & 0.097 & $(0.006 ; 0.189)$ \\
\hline
\end{tabular}


Table A.1. Studies in which covariates were directly linked to the lead in dust or indirectly (via the blood lead level).

\begin{tabular}{|c|c|}
\hline Covariate label & Studies \\
\hline Floor entrance & (Tong and Lam, 2000) \\
\hline Season & $\begin{array}{l}\text { (Laxen et al., 1988), (Yiin et al., 2000), (Laidlaw et al., 2005), (Laidlaw and Filippelli, 2008), } \\
\text { (Mielke et al., 2010), (Clark et al., 2011), (Dixon et al., 2012) }\end{array}$ \\
\hline Wet cleaning landing floor & (Gaitens et al., 2009) \\
\hline Type of room & (Wilson et al., 2007) \\
\hline Wet cleaning freq-room & (Yiin et al., 2003), (Bretin, 2006), (Gaitens et al., 2009) \\
\hline \multicolumn{2}{|l|}{ Dry cleaning freq-room } \\
\hline Dust sample location & (U.S. HUD, 2003), (Bretin, 2006), (Wilson et al., 2007) \\
\hline Number of activities at risk & (Sanborn et al., 2002), (Schapiro and Bretin, 2006) \\
\hline XRF ext railings & (Gibson, 2005) \\
\hline Ext playground soil & $\begin{array}{l}\text { (Fergusson et al., 1986), (Thornton et al., 1990), (Succop et al., 1998), (Clark et al., 2004), (Dixon } \\
\text { et al., 2005b), (Caravanos et al., 2006), (Dixon et al., 2008), (Hunt et al., 2006), (Hunt et al., 2012) }\end{array}$ \\
\hline Ext playground dust & \\
\hline
\end{tabular}




\begin{tabular}{|c|c|}
\hline Covariate label & Studies \\
\hline DPb-landing & (Dixon et al., 2005b) \\
\hline Annual vehicle traffic & (Sheets et al., 2001), (Mielke et al., 2010), (Mielke et al., 2011) \\
\hline Surrounding demolition & (Farfel et al., 2003), (Farfel et al., 2005), (Rabito et al., 2007), (Dixon et al., 2012) \\
\hline Leisure freq & (Hozhabri et al., 2004), (Schapiro and Bretin, 2006) \\
\hline Ext work & $\begin{array}{l}\text { (Rabinowitz et al., 1985), (U.S. EPA, 2000), (Reissman et al., 2002), (Dixon et al., 2005a), (Clark } \\
\text { et al., 2011), (Dixon et al., 2012) }\end{array}$ \\
\hline Int work & \\
\hline Polluting sites & (Davies et al., 1985), (Cook et al., 1993), (Lanphear et al., 2003) \\
\hline Contaminated sites & $\begin{array}{l}\text { (Davies et al., 1987), (Lanphear and Roghmann, 1997), (Lanphear et al., 2003), (Clark et al., } \\
\text { 2004), (Hunt et al., 2006) }\end{array}$ \\
\hline Lead emissions in air & (Layton and Beamer, 2009) \\
\hline Smoking inside & (Gaitens et al., 2009) \\
\hline XRF sum-deteriorated & $\begin{array}{l}\text { (Sturges and Harrison, 1985), (U.S. HUD, 1995), (Lanphear and Roghmann, 1997), (Farley, 1998), } \\
\text { (Succop et al., 1998), (CDC, 2007), (Beauchemin et al., 2011), (Dixon et al., 2012) }\end{array}$ \\
\hline XRF sum-usual condition & \\
\hline
\end{tabular}


Table A.2. Variables of the fitted 2-level model and their description.

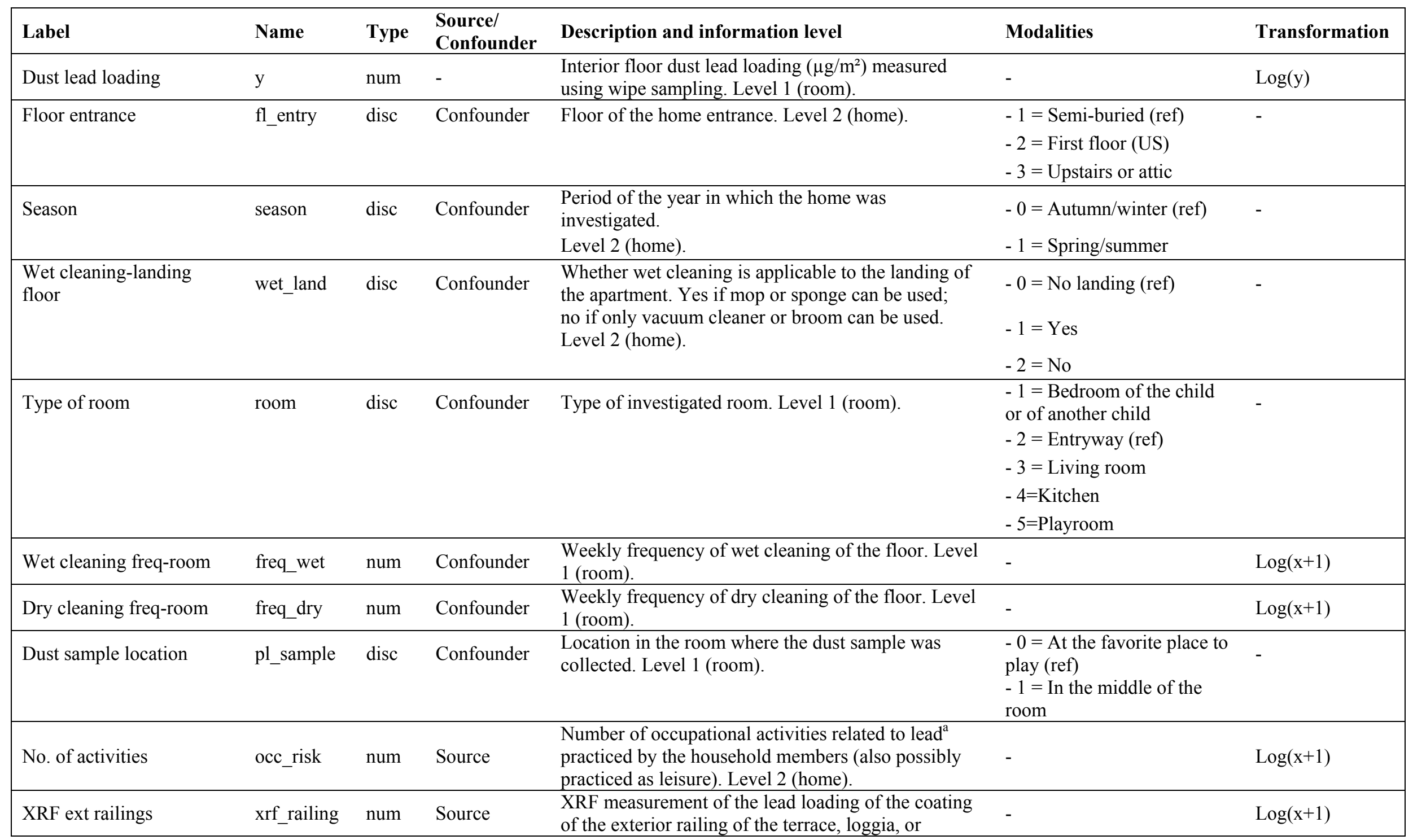




\begin{tabular}{|c|c|c|c|c|c|c|}
\hline Label & Name & Type & $\begin{array}{l}\text { Source/ } \\
\text { Confounder }\end{array}$ & Description and information level & Modalities & Transformation \\
\hline & & & & $\begin{array}{l}\text { balcony; set to } 0 \text { if no exterior railings. Level } 2 \\
\text { (home). }\end{array}$ & & \\
\hline \multirow[t]{3}{*}{ Ext playground soil ${ }^{\mathrm{b}}$} & \multirow[t]{3}{*}{ pb_soil } & \multirow[t]{3}{*}{$\begin{array}{l}\operatorname{num} \times \\
\operatorname{disc}\end{array}$} & \multirow[t]{3}{*}{ Source } & $\begin{array}{l}\text { Interaction: lead concentration }(\mathrm{mg} / \mathrm{kg}) \text { of the soil of } \\
\text { the outdoor play area of the child } \times \text { how often the } \\
\text { child plays in this play area. }\end{array}$ & $\begin{array}{l}\text { - } 0=\text { The child does not play } \\
\text { outside (ref) }\end{array}$ & \multirow[t]{3}{*}{$\log (x+1)$} \\
\hline & & & & $\begin{array}{l}\text { The lead concentration is set to } 0 \text { if there is no } \\
\text { outdoor play area or if the play area is on a hard } \\
\text { surface. }\end{array}$ & $\begin{array}{l}-1=\text { The child often plays in } \\
\text { this play area }\end{array}$ & \\
\hline & & & & Level 2 (home). & $\begin{array}{l}-2=\text { The child plays in this } \\
\text { play area always }\end{array}$ & \\
\hline \multirow[t]{3}{*}{ Ext playground dust $\mathrm{c}^{\mathrm{c}}$} & \multirow[t]{3}{*}{ pb_hard } & \multirow[t]{3}{*}{$\begin{array}{l}\text { num } \times \\
\operatorname{disc}\end{array}$} & \multirow[t]{3}{*}{ Source } & $\begin{array}{l}\text { Interaction: lead loading }\left(\mu \mathrm{g} / \mathrm{m}^{2}\right) \text { of the outdoor play } \\
\text { area of the child when it is on a hard surface } \times \text { how } \\
\text { often the child plays in this play area. }\end{array}$ & $\begin{array}{l}-0=\text { The child does not } \\
\text { play outside (ref) }\end{array}$ & \multirow[t]{3}{*}{$\log (x+1)$} \\
\hline & & & & $\begin{array}{l}\text { The lead loading is set to } 0 \text { if there is no outdoor play } \\
\text { area or if the play area is on soil. }\end{array}$ & \multirow{2}{*}{$\begin{array}{l}-1=\text { The child often plays in } \\
\text { this play area } \\
-2=\text { The child plays in this } \\
\text { play area always }\end{array}$} & \\
\hline & & & & Level 2 (home). & & \\
\hline DPb-landing & pb_land & num & Source & $\begin{array}{l}\text { Floor dust lead loading }\left(\mu \mathrm{g} / \mathrm{m}^{2}\right) \text { of the landing of the } \\
\text { apartment measured using wipe sampling; set to } 0 \text { if } \\
\text { no landing. Level } 2 \text { (home). }\end{array}$ & 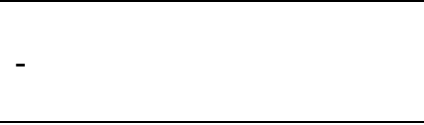 & $\log (x+1)$ \\
\hline Annual vehicle traffic & n_car & num & Source & $\begin{array}{l}\text { Annual flow of vehicles on the closest road to the } \\
\text { home divided by the distance }(\mathrm{km}) \text { between the road } \\
\text { and the home. Level } 2 \text { (home). }\end{array}$ & - & $\log (\mathrm{x})$ \\
\hline \multirow[t]{2}{*}{ Surrounding demolition } & \multirow[t]{2}{*}{ old_build } & \multirow[t]{2}{*}{ disc } & \multirow[t]{2}{*}{ Source } & $\begin{array}{l}\text { Old buildings within a radius of } 50 \mathrm{~m} \text {. Have they } \\
\text { been demolished or renovated in the past? }\end{array}$ & $-1=$ Yes & \multirow[t]{2}{*}{-} \\
\hline & & & & Level 2 (home). & $-2=$ No (ref) & \\
\hline Leisure freq ${ }^{\mathrm{d}}$ & leisure & num & Source & $\begin{array}{l}\text { How often a hobby related to lead is practiced inside } \\
\text { the home? (Number of times per year). Level } 2 \\
\text { (home). }\end{array}$ & - & $\log (x+1)$ \\
\hline \multirow[t]{2}{*}{ Ext work $^{\mathrm{e}}$} & \multirow[t]{2}{*}{ extwork } & \multirow[t]{2}{*}{$\operatorname{disc}$} & \multirow[t]{2}{*}{ Source } & \multirow[t]{2}{*}{$\begin{array}{l}\text { Whether work outside the home was performed in the } \\
\text { past } 6 \text { months before the survey. Level } 2 \text { (home). }\end{array}$} & $-1=$ Yes & - \\
\hline & & & & & $-2=$ No (ref) & \\
\hline \multirow[t]{2}{*}{ Int work ${ }^{\mathrm{f}}$} & \multirow[t]{2}{*}{ inwork } & \multirow[t]{2}{*}{$\operatorname{disc}$} & \multirow[t]{2}{*}{ Source } & \multirow[t]{2}{*}{$\begin{array}{l}\text { Whether work inside the home was performed in the } \\
\text { past } 6 \text { months before the survey. Level } 2 \text { (home). }\end{array}$} & $-1=$ Yes & \multirow[t]{2}{*}{-} \\
\hline & & & & & $-2=$ No (ref) & \\
\hline
\end{tabular}




\begin{tabular}{|c|c|c|c|c|c|c|}
\hline Label & Name & Type & $\begin{array}{l}\text { Source/ } \\
\text { Confounder }\end{array}$ & Description and information level & Modalities & Transformation \\
\hline Polluting sites & basias & num & Source & $\begin{array}{l}\text { Score assigned to industrial sites or service activities } \\
\text { around the home, current or former, having a } \\
\text { potentially polluting activity (lead). See details in the } \\
\text { text for the construction of this variable. Level } 2 \\
\text { (home). }\end{array}$ & - & $\log (x+1)$ \\
\hline Contaminated sites & basol & num & Source & $\begin{array}{l}\text { Score about polluted sites and soils (potentially lead } \\
\text { contaminated) around the home, involving a } \\
\text { government action, preventive or curative. See details } \\
\text { in the text for the construction of this variable. Level } \\
2 \text { (home). }\end{array}$ & - & $\log (x+1)$ \\
\hline Lead emission in air & bdrep & num & Source & $\begin{array}{l}\text { Score about the lead emission in air of plants subject } \\
\text { to authorization (industrial plant and stockbreeding). } \\
\text { See details in the text for the construction of this } \\
\text { variable. Level } 2 \text { (home). }\end{array}$ & - & $\log (x+1)$ \\
\hline Smoking inside & smoking & num & Source & $\begin{array}{l}\text { Average daily time when someone smokes inside the } \\
\text { home. Level } 2 \text { (home). }\end{array}$ & - & $\log (x+1)$ \\
\hline XRF sum-deteriorated & det_xrf & num & Source & $\begin{array}{l}\text { Sum of the maximal XRF measurements of each } \\
\text { diagnosis unit }^{\mathrm{g}} \text { of the room. Only diagnosis units with } \\
\text { a deteriorated coating }{ }^{\mathrm{h}} \text {. Level } 1 \text { (room). }\end{array}$ & - & $\log (x+1)$ \\
\hline XRF sum-usual condition & use_xrf & num & Source & $\begin{array}{l}\text { Sum of the maximal XRF measurements of each } \\
\text { diagnosis unit of the room. Only diagnosis units with } \\
\text { a coating in usual condition. Level } 1 \text { (room). }\end{array}$ & - & $\log (x+1)$ \\
\hline
\end{tabular}

num: numeric; disc: discrete; ref: reference category.

a: mining and metallurgy of lead (including the recovery of metals and batteries) and zinc; manufacture of welding sticks or welding wires; manufacture of storage batteries; manufacture of pigments, paints, varnishes containing inorganic compounds of lead, as well as their application in aerosol (spray) or machining; linotype and letterpress (printing processes being abandoned); manufacture of protection against ionizing radiation; manufacture and use of ammunition; production of glass (particularly crystal); production and use of enamels; manufacture or renovation of stained-glass windows; production or processing of plastics containing lead, used as a pigment or stabilizer; production and use of lubricants containing lead; repairing car radiators; iron, carving, or machining leaded bronzes; installing or removing lead pipes; demolition of old buildings; thermal stripping or sanding old paint or anti-rust paints; installation and removal of lead articles on roofs, terraces, or balconies; use of films or plates of lead for insulation against noise, vibrations, and/or humidity; torch cutting of painted scrap; installation and removal of protective steel cables or telephone lines

b: for instance, bare soil or grass

c: for example, macadam or concrete

d: pottery, enamel; work on stained-glass windows; making toy soldiers, models, or decorative objects, including parts coated with lead or leaded paint; melting of lead pellets (hunting), sinkers, scuba-diving weights; stripping paint off antique furniture, vehicles, boats, etc.

e: replacement of windows or doors; repainting; paint stripping; paint sandblast; facelift

f: replacement of windows or doors; repainting; paint stripping 
g: a diagnosis unit is defined as one or several parts of a building construction having the same substrate and the same history in terms of construction and coating h: chalking, chipping, blistering, cracking, alligatoring, tracks of scratching, etc.

i: tracks of shocks, micro-cracking. 
The score of the variables labeled "Polluting sites," "Contaminated sites," and "Lead emission in air" were built in the following manner. For each investigated dwelling, we calculated the "Polluting sites" score by $\sum_{k}\left(1 / d_{k}\right)$, where $d_{k}$ is the distance $(\mathrm{km})$ between the home and the $k^{\text {th }}$ site identified, such as a polluting site. Only the polluting sites within a $2-\mathrm{km}$ radius around the home were considered. The "Contaminated sites" variable was built in the same way. The "Lead emission in air" score was built by $\sum_{k}\left(f_{k} / d_{k}\right)$, where $f_{k}$ is the lead emission (kg/year) of the $k^{\text {th }}$ site. For each of these 3 variables, we also calculated another 9 similar variables for radius $1 \mathrm{~km}, 3 \mathrm{~km}, \ldots, 10 \mathrm{~km}$, but these 10 variables were very closely correlated, thus providing similar information. We dropped the variables with a radius equal to $1 \mathrm{~km}$ because the uncertainty of the distance between the home and the site could equal $1 \mathrm{~km}$, and we finally kept the 2-km radius variables because we assumed that the closer the site, the more likely its impact on the home. Data about "Polluting sites," "Contaminated sites," and "Lead emission in air" came from the French public national databases "Basias" (MEEDDTL and BRGM 2011), “Basol” (MEEDDTL 2011), and “BD REP” (MEEDDTL and INERIS 2003), respectively. Data for the "Annual vehicle traffic" variable came from the European Open Street Map (Geofabrik 2008) database. For each housing unit, the "Annual vehicle traffic" value was calculated by $n / d$, where $n$ is the annual flow of vehicles per year on the closest road to the home and $d$ is the distance in km between the home and the road.

If the child played outside on a hard surface, the value of the "Ext playground soil" variable was set to 0 ; otherwise, the value would have been treated as missing by the statistical software. If the child played outside on soil, the value of the "Ext playground dust" variable was set to 0 . Such a 0 value obviously does not represent the lead level of exterior dust and soil near the housing unit. Thus, the "Ext playground soil" and "Ext playground dust" variables were introduced in an interaction with the frequency of visit of the play area by the child to assess the track-in phenomenon only. In addition, the overall level of lead 
contamination in soils and exterior dust in the neighborhood was approached via the "Polluting sites" and "Contaminated sites" variables. The "Annual vehicle traffic" variable was also used to help quantify this outdoor lead level close to each housing unit based on the past contamination due to lead in gasoline.

\section{Appendix B. Supporting information}

Supplementary data associated with this article can be found in the online version at

\section{See attached file on HAL bibliographic record}

\section{Acknowledgments}

The authors wish to thank the members of the Steering Committee (COPIL) of the PlombHabitat survey.

\section{Conflict of Interest}

None.

\section{References}

ACCLPP. Low level lead exposure harms children: a renewed call for primary prevention. Atlanta, GA: US Department of Health and Human Services, CDC, Advisory Committee on Childhood Lead Poisoning Prevention; 2012. Available from: http://www.cdc.gov/nceh/lead/acclpp/final_document_030712.pdf (accessed 1 Oct. 2013)

AFNOR. Soil quality - Pretreatment of samples for physico-chemical analysis. NF ISO 11464. Association Française de Normalisation: La Plaine Saint-Denis; December 2006. 
AFNOR. Lead diagnosis — Protocol for establishing the risk of exposure to lead. NF X 46030. Association Française de Normalisation: La Plaine Saint-Denis; April 2008a.

AFNOR. Lead diagnosis - Chemical analysis of paints for determining the acido-soluble fraction of lead. NF X 46-031. Association Française de Normalisation: La Plaine Saint-Denis; April 2008b.

AFNOR. Lead diagnosis - Methodology for measuring lead in floor dust. NF X 46-032. Association Française de Normalisation: La Plaine Saint-Denis; April 2008c.

ASTM. Standard Practice for Collection of Settled Dust Samples Using Wipe Sampling Methods for Subsequent Lead Determination. ASTM E 1728 - 03. American Society for Testing and Materials: West Conshohocken, PA; 2003.

Beauchemin S, MacLean LCW, Rasmussen PE. Lead speciation in indoor dust: a case study to assess old paint contribution in a Canadian urban house. Environ. Geochem. Heal. 2011;33:343-52.

Bretin P. Guide d'investigation environnementale des cas de saturnisme de l'enfant. Guide méthodologique. Saint-Maurice: InVS/DSE; 2006.

Canfield RL, Henderson CR, Cory-Slechta DA, Cox C, Jusko TA, Lanphear BP. Intellectual Impairment in Children with Blood Lead Concentrations below $10 \mu \mathrm{g}$ per Deciliter. N. Engl. J. Med. 2003;348:1517-26.

Caravanos J, Weiss AL, Jaeger RJ. An exterior and interior leaded dust deposition survey in New York City: Results of a 2-year study. Environ. Res. 2006;100:159-64.

Carle A. Fitting multilevel models in complex survey data with design weights: Recommendations. Bmc Med. Res. Methodol. 2009;9:49. 
CDC. Interpreting and Managing Blood Lead Levels $<10 \mu \mathrm{g} / \mathrm{dL}$ in Children and Reducing Childhood Exposures to Lead. Rep. 56 (RR-8). Centers for Disease Control and Prevention; 2007 p. 1-16. Report No.: Rep. 56 (RR-8).

CDC. Response to Advisory Committee on Childhood Lead Poisoning Prevention recommendations in Low level lead exposure harms children: a renewed call for primary prevention. Atlanta, GA: Centers for Disease Control and Prevention, US Department of Health and Human Services; 2012. Available from: http://www.cdc.gov/nceh/lead/ACCLPP/CDC_Response_Lead_Exposure_Recs.pdf (accessed 1 Oct. 2013)

Clark S, Galke W, Succop P, Grote J, McLaine P, Wilson J, et al. Effects of HUD-supported lead hazard control interventions in housing on children's blood lead. Environ. Res. 2011;111:301-11.

Clark S, Menrath W, Chen M, Succop P, Bornschein R, Galke W, Wilson J. The influence of exterior dust and soil lead on interior dust lead levels in housing that had undergone lead-based paint hazard control. J. Occup. Environ. Hyg. 2004;1:273-82.

Cook M, Chappell WR, Hoffman RE, Mangione EJ. Assessment of Blood Lead Levels in Children Living in a Historic Mining and Smelting Community. Am. J. Epidemiol. $1993 ; 137: 447-55$.

Davies BE, Elwood PC, Gallacher J, Ginnever RC. The relationships between heavy metals in garden soils and house dusts in an old lead mining area of North Wales, Great Britain. Environ. Pollut. Ser. B Chem. Phys. 1985;9:255-66.

Davies DJA, Watt JM, Thornton I. Lead levels in Birmingham dusts and soils. Sci. Total Environ. 1987;67:177-85. 
Dixon S, Wilson J, Kawecki C, Green R, Phoenix J, Galke W, Clark S, Breysse J. Selecting a lead hazard control strategy based on dust lead loading and housing condition: I. Methods and results. J. Occup. Environ. Hyg. 2008;5:530-9.

Dixon SL, Jacobs DE, Wilson JW, Akoto JY, Nevin R, Scott Clark C. Window replacement and residential lead paint hazard control 12 years later. Environ. Res. 2012;113:14-20.

Dixon SL, Wilson JW, Clark CS, Galke WA, Succop PA, Chen M. Effectiveness of leadhazard control interventions on dust lead loadings: Findings from the evaluation of the HUD Lead-Based Paint Hazard Control Grant Program. Environ. Res. 2005a;98:30314.

Dixon SL, Wilson JW, Clark CS, Galke WA, Succop PA, Chen M. The Influence of Common Area Lead Hazards and Lead Hazard Control on Dust Lead Loadings in Multiunit Buildings. J. Occup. Environ. Hyg. 2005b;2:659-66.

Etchevers A, Lecoffre C, Le Tertre A, Le Strat Y, Groupe Investigateurs S-I, De Launay C, et al. Blood lead level in children in France, 2008-2009. BEHweb 2010.

Falq G, Zeghnoun A, Pascal M, Vernay M, Le Strat Y, Garnier R, Olichon D, Bretin P, Castetbon K, Fréry N. Blood lead levels in the adult population living in France the French Nutrition and Health Survey (ENNS 2006-2007). Environ. Int. 2011;37:56571.

Farfel MR, Orlova AO, Lees PSJ, Rohde C, Ashley PJ, Chisolm JJ. A Study of Urban Housing Demolitions as Sources of Lead in Ambient Dust: Demolition Practices and Exterior Dust Fall. Environ. Health Perspect. 2003;111:1228-34. 
Farfel MR, Orlova AO, Lees PSJ, Rohde C, Ashley PJ, Julian Chisolm Jr. J. A study of urban housing demolition as a source of lead in ambient dust on sidewalks, streets, and alleys. Environ. Res. 2005;99:204-13.

Farley D. Dangers of Lead Still Linger. Us Food Drug Adm. 1998;16-21.

Fergusson JE, Forbes EA, Schroeder RJ, Ryan DE. The elemental composition and sources of house dust and street dust. Sci. Total Environ. 1986;50:217-21.

Gaitens JM, Dixon SL, Jacobs DE, Nagaraja J, Strauss W, Wilson JW, Ashley PJ. Exposure of U.S. children to residential dust lead, 1999-2004: I. Housing and demographic factors. Environ. Health Perspect. 2009;117:461-7.

Geofabrik. European Open Street Map. 2008. Available at: http://freegeographytools.com/2008/european-open-street-map-osm-data-in-shapefileformat.

Gibson JL. A plea for painted railings and painted walls of rooms as the source of lead poisoning amongst Queensland children. 1904. Public Heal. Reports Wash. Dc 1974 $2005 ; 120: 301-4$.

Harrell FE. Regression modeling strategies: with applications to linear models, logistic regression, and survival analysis. New York: Springer; 2001.

Hozhabri S, White F, Rahbar MH, Agboatwalla M, Luby S. Elevated blood lead levels among children living in a fishing community, Karachi, Pakistan. Arch. Environ. Health 2004;59:37-41.

Hunt A, Johnson DL, Griffith DA. Mass transfer of soil indoors by track-in on footwear. Sci. Total Environ. 2006;370:360-71. 
Hunt A, Johnson DL, Griffith DA, Zitoon S. Citywide distribution of lead and other element in soils and indoor dusts in Syracuse, NY. Appl. Geochem. 2012;27:985-94.

INSERM. Plomb dans l'environnement : quels risques pour la santé ? Les éditions Inserm. Institut National de la Santé et de la Recherche Médicale: Paris; 1999.

Jiang Q, Succop PA. A Study of the Specification of the Log-Log and Log-Additive Models for the Relationship between Blood Lead and Environmental Lead. J. Agric. Biol. Environ. Stat. 1996;1:426-34.

Kim JK, Michael Brick J, Fuller WA, Kalton G. On the bias of the multiple-imputation variance estimator in survey sampling. J. R. Stat. Soc. Ser. B Stat. Methodol. 2006;68:509-21.

Kramer MH. R2 statistics for mixed models. Presented at the 17th Annual Kansas State University Conference on Applied Statistics in Agriculture. Manhattan, KS; 2005. p. 148-60.

Laidlaw MAS, Filippelli GM. Resuspension of urban soils as a persistent source of lead poisoning in children: A review and new directions. Appl. Geochem. 2008;23:202139.

Laidlaw MAS, Mielke HW, Filippelli GM, Johnson DL, Gonzales CR. Seasonality and Children's Blood Lead Levels: Developing a Predictive Model Using Climatic Variables and Blood Lead Data from Indianapolis, Indiana, Syracuse, New York, and New Orleans, Louisiana (USA). Environ. Health Perspect. 2005;113:793-800.

Lanphear BP, Hornung R, Ho M, Howard CR, Eberly S, Knauf K, Eberle S. Environmental lead exposure during early childhood. J. Pediatr. 2002;140:40-7. 
Lanphear BP, Hornung R, Khoury J, Yolton K, Baghurst P, Bellinger DC, et al. Low-Level Environmental Lead Exposure and Children's Intellectual Function: An International Pooled Analysis. Environ. Health Perspect. 2005;113:894-9.

Lanphear BP, Matte T, Rogers J, Clickner R, Dietz B, Bornschein R, et al. The Contribution of Lead-Contaminated House Dust and Residential Soil to Children's Blood Lead Levels: A Pooled Analysis of 12 Epidemiologic Studies. Environ. Res. 1998;79:5168.

Lanphear BP, Roghmann KJ. Pathways of Lead Exposure in Urban Children. Environ. Res. 1997;74:67-73.

Lanphear BP, Succop P, Roda S, Henningsen G. The effect of soil abatement on blood lead levels in children living near a former smelting and milling operation. Public Health Rep. 2003;118:83-91.

Lanphear BP, Weitzman M, Winter N, Eberly S, Yakir B, Tanner M, Emond M, Matte T. Lead-contaminated house dust and urban children's blood lead levels. Am. J. Public Health 1996;86:1416-21.

Laxen DPH, Lindsay F, Raab GM, Hunter R, Fell GS, Fulton M. The variability of lead in dusts within the homes of young children. Environ. Geochem. Heal. 1988;10:3-9.

Layton DW, Beamer PI. Migration of Contaminated Soil and Airborne Particulates to Indoor Dust. Environ. Sci. Technol. 2009;43:8199-205.

Le Bot B, Arcelin C, Briand E, Glorennec P. Sequential digestion for measuring leachable and total lead in the same sample of dust or paint chips by ICP-MS. J. Environ. Sci. Heal. Part 2011;46:63-9. 
Lubin JH, Colt JS, Camann D, Davis S, Cerhan JR, Severson RK, Bernstein L, Hartge P. Epidemiologic Evaluation of Measurement Data in the Presence of Detection Limits. Environ. Health Perspect. 2004;112:1691-6.

Lucas J-P. Historique de la règlementation relative à l'emploi de la céruse et des dérivés du plomb dans la peinture en France. Environ. Risques Santé 2011;10:316-22.

Lucas J-P, Le Bot B, Glorennec P, Etchevers A, Bretin P, Douay F, Sébille V, Bellanger L, Mandin C. Lead contamination in French children's homes and environment. Environ. Res. 2012;116:58-65.

Lucas J-P, Sébille V, Le Tertre A, Le Strat Y, Bellanger L. Multilevel modelling of survey data: impact of the 2-level weights used in the pseudolikelihood. J Appl Stat. 2013;In Press. doi:10.1080/02664763.2013.847404

MEEDDTL. Soils Pollution BASOL. Department of Ecology, Sustainable Development, Transport and Housing. 2011. Available at: http://basol.environnement.gouv.fr/.

MEEDDTL, BRGM. Inventory of historic industrial sites and service activities BASIAS. Department of Ecology, Sustainable Development, Transport and Housing. 2011. Available at: http://basias.brgm.fr/.

MEEDDTL, INERIS. French registry of polluting emissions. BDREP. 2003. Available at: http://www.irep.ecologie.gouv.fr/IREP/index.php.

Mielke HW, Laidlaw MAS, Gonzales C. Lead $(\mathrm{Pb})$ legacy from vehicle traffic in eight California urbanized areas: Continuing influence of lead dust on children's health. Sci. Total Environ. 2010;408:3965-75. 
Mielke HW, Laidlaw MAS, Gonzales CR. Estimation of leaded $(\mathrm{Pb})$ gasoline's continuing material and health impacts on 90 US urbanized areas. Environ. Int. 2011;37:248-57.

Oulhote Y, Tertre AL, Etchevers A, Bot BL, Lucas J-P, Mandin C, Strat YL, Lanphear B, Glorennec P. Implications of different residential lead standards on children's blood lead levels in France: Predictions based on a national cross-sectional survey. Int. J. Hyg. Environ. Health in press. http://dx.doi.org/10.1016/j.ijheh.2013.02.007

Pfeffermann D, Skinner CJ, Holmes DJ, Goldstein H, Rasbash J. Weighting for unequal selection probabilities in multilevel models. J. R. Stat. Soc. Ser. B Stat. Methodol. 1998;60:23-40.

Rabe-Hesketh S, Skrondal A. Multilevel modelling of complex survey data. J. R. Stat. Soc. Ser. A Stat. Soc. 2006;169:805-27.

Rabe-Hesketh S, Skrondal A, Zheng X. 10 - Multilevel Structural Equation Modeling. In: SikYum Lee, editor. Handb. Latent Var. Relat. Models. North-Holland: Amsterdam; 2007. p. 209-27.

Rabinowitz M, Leviton A, Bellinger D. Home refinishing, lead paint, and infant blood lead levels. Am. J. Public Health 1985;75:403-4.

Rabito FA, Iqbal S, Shorter CF, Osman P, Philips PE, Langlois E, White LE. The association between demolition activity and children's blood lead levels. Environ. Res. 2007;103:345-51.

Reissman DB, Matte TD, Gurnitz KL, Kaufmann RB, Leighton J. Is home renovation or repair a risk factor for exposure to lead among children residing in New York City? J. Urban Heal. Bull. New York Acad. Med. 2002;79:502-11. 
Reiter JP, Raghunathan TE, Kinney SK. The importance of modeling the sampling design in multiple imputation for missing data. Surv. Methodol. 2006;32:143-9.

Rosner B (Bernard A). Fundamentals Of Biostatistics. Boston, MA: Cengage Learning; 2006.

Rust SW, Burgoon DA, Lanphear BP, Eberly S. Log-Additive versus Log-Linear Analysis of Lead-Contaminated House Dust and Children's Blood-Lead Levels. Environ. Res. 1997;72:173-84.

Sanborn MD, Abelsohn A, Campbell M, Weir E. Identifying and managing adverse environmental health effects: 3. Lead exposure. Can. Med. Assoc. J. 2002;166:128792.

Schapiro E, Bretin P. Sources inhabituelles d'intoxication par le plomb chez l'enfant et la femme enceinte. Saint-Maurice: InVS/DSE; 2006.

Sheets RW, Kyger JR, Biagioni RN, Probst S, Boyer R, Barke K. Relationship between soil lead and airborne lead concentrations at Springfield, Missouri, USA. Sci. Total Environ. 2001;271:79-85.

StataCorp. Stata Base reference manual Release 12. Stata Press: College Station, TX; 2011.

Sterling DA, Johnson DL, Murgueytio AM, Evans RG. Source contribution of lead in house dust from a lead mining waste superfund site. J. Expo. Anal. Environ. Epidemiol. 1998;8:359-73.

Sterne JAC, White IR, Carlin JB, Spratt M, Royston P, Kenward MG, Wood AM, Carpenter JR. Multiple imputation for missing data in epidemiological and clinical research: potential and pitfalls. BMJ 2009;338:b2393. 
Sturges WT, Harrison RM. An assessment of the contribution from paint flakes to the lead content of some street and household dusts. Sci. Total Environ. 1985;44:225-34.

Succop P, Bornschein R, Brown K, Tseng CY. An empirical comparison of lead exposure pathway models. Environ. Health Perspect. 1998;106:1577-83.

Thornton I, Davies DJ, Watt JM, Quinn MJ. Lead exposure in young children from dust and soil in the United Kingdom. Environ. Health Perspect. 1990;89:55-60.

Tong STY, Lam KC. Home sweet home? A case study of household dust contamination in Hong Kong. Sci. Total Environ. 2000;256:115-23.

U.S. EPA. Lead Exposure Associated with Renovation and Remodelling Activities - Final summary report. EPA 747-S-00-001. January 2000.

U.S. HUD. Guidelines for the Evaluation and Control of Lead-Based Paint Hazards in Housing. Chapter 5: Risk Assessment. U.S. Department of Housing and Urban Development: Washington, DC; 1995.

U.S. HUD. An Evaluation of Residual Lead Dust Following Lead Abatement Clean-up and Clearance Activities. Final Report. U.S. Department of Housing and Urban Development: Washington, DC; 2003.

Van Buuren S, Boshuizen HC, Knook DL. Multiple imputation of missing blood pressure covariates in survival analysis. Stat. Med. 1999;18:681-94.

White IR, Royston P, Wood AM. Multiple imputation using chained equations: Issues and guidance for practice. Stat. Med. 2011;30:377-99.

Wilson J, Dixon S, Galke W, McLaine P. An investigation of dust lead sampling locations and children's blood lead levels. J. Expo. Sci. Environ. Epidemiol. 2007;17:2-12. 
Yiin L-M, Lioy PJ, Rhoads GG. Impact of home carpets on childhood lead intervention study. Environ. Res. 2003;92:161-5.

Yiin LM, Rhoads GG, Lioy PJ. Seasonal influences on childhood lead exposure. Environ. Health Perspect. 2000;108:177-82 